\title{
Shiraliyeva S.J.*
}

DOI: 10.25108/2304-1730-1749.iolr.2017.50.255-273

\section{Situational conditionality of structural elements of integrative criminalistical tactics}

\begin{abstract}
Distinction of investigative situations determines the tactics of specific investigative actions and rightness of investigator's actions in forming situation in great extent depends on his correct assessment of the latter. Correct assessment of investigative situation and a choice in this base the tactics of investigation are important conditions of investigation's purposefulness, adoption of scientifically substantiated and optimal solutions of the tactical, methodological and technical criminalistical nature. However, it should be taken into account that awareness and experience of real situation by the participants of preliminary investigation have always probabilistic character and it is impossible to take into consideration all variety of the factors that impact on a content of procedural tactical situation. Consequently, situational conditionality of the tactical techniques associated with objective (a set of the factors, circumstances) and subjective moments (evaluative behaviour of investigator).
\end{abstract}

Keywords: integrative criminalistical tactics; situation; investigative action; information; repeatability.

Structural elements of integrative criminalistical tactics (hereinafter, the ICT) and their systems are in situational dependence as actions of investigator, prosecutor, judge and others in any cases associated with character of situation: from all set of known him techniques they have to chose at this time the most appropriate.

\footnotetext{
- Shiraliyeva Sabina Javanshir gyzy - PhD in Law, a member of Council of International Organization for Legal Researches (Azerbaijan). E-mail: mopi_sid@yahoo.com
} 
Issues of the situation in criminalistical literature have been paid great attention [1, p. 85-104; 10, p. 50-98; 13, p. 106-120; 17, p. 28-34]. R.S. Belkin was one of the firsts who had taken attention at significance of investigation situation and necessity its registration for effective usage of criminalistical recommendations was [4, p. 267-288]. In his works he pointed that investigative situation is related to number of the notions of criminalistical tactics and in this capacity like other tactical criminalistical notions is realized in criminalistical method [3, p. 70-72].

Nevertheless, there is no unity of views concerning the notion of investigative situation among the criminalists: ones authors determine the investigative situation as a set of conditions, in which in this time investigation is carried out, i.e. an environment, in which a process of proving runs [2, p. 69-71]; others authors are considering the situation as a set of circumstances on a case, which might be favourable or unfavourable for any conclusions and actions of investigator [5, c. 81-83] or like a set of actual data, which reflect the essential features of an event, what it seems to be at that or other stage of crimes' investigation.

Most authors justly point in dynamic nature of investigative situation and there are impacted different factors on it, in force of which it might be occurred its alteration and dependence on volume of available criminalistically significant information is formed favourable or unfavourable situations. It is noted that investigative situation is some movable, continuously changing condition of investigation [10, p. 54-56], it is managed system that might be purposefully modified [12, p. 165-168], modification of investigatory situation might be associated with right or wrong realization of tactical techniques, their complexes, systems, which assist obtaining of certain information [11, p. 159].

Scientists-criminalists are considered different kinds of investigative situation and are suggested their characteristics, among of which it seems to be interesting a classification of investigative situation given by L.Y. Drapkin. He distinguishes a simple and complex of investigatory situations, and dependence on number, nature and content of forming factors all complicated situations are differentiated into 
classification groups: problem, conflict, tactical risk, organizational non-ordered and combinational (mixed) situations [8, p. 8-12]. In opinion of R.S. Belkin, from number of existing classifications of investigative situations substantiated is their division into typical and specific; initial, interim and final; non-conflict and conflict (with further their subdivision) [3, p. 74-76].

It is generally known that difference of investigative situation determines the tactics of concrete investigative actions, and rightness of investigator's actions in formed situation in great extent depends on his correct assessment of the latter. Correct assessment of investigative situations and a choice of the investigation's tactics are significant conditions of investigation's purposefulness, adoption of scientifically substantiated and optimal decisions of tactical, method and technical criminalistical nature. But, it needs to take in account that awareness and experience of real situation by participants of preliminary investigation have always probabilistic nature and it is impossible to take into account all diversity of the factors influencing in a content of procedural tactical situation. Consequently, situational conditionality of the tactical techniques associated with objective (a set of the factors, circumstances) and subjective moments (evaluative behaviour of investigator).

Most part of the authors relate to number of objective factors: presence and nature of available to investigator evidential and orienting information that depends on mechanism of investigated event and conditions of appearance its traces in environment; availability and sustainability of existence not used sources of evidential information and reliable channels of receiving of orienting information; intensity of the processes of disappearance of evidences and power of the factors that influence to these processes; availability at this time in disposal of investigator, inquiry body necessary powers, means, time and opportunity their optimal using; criminal legal assessment of investigated event existing at this moment [1, p. 92].

The same time, the following is related to subjective factors: mental state of persons involving in investigated case; mental state of investigator, level his 
knowledge and abilities, practical experience, ability to make and fulfill decisions in extreme conditions; contraction establishing truth from criminal and his ties, and sometimes from victim and witnesses; favourable (non-conflict) course of investigation; efforts of investigator, directed to alteration of investigative situation in desirable side; consequences of wrong actions of investigator, operation worker, expert, attesting witnesses; consequences of data's disclosure of preliminary investigation; unforeseen actions of victim or persons not involved in investigated event [1, p. 92-93].

It is established that situation actively impact on a choice of tactical techniques directed to achievement of appropriate aims. Correlations between a choice of tactical techniques and investigative situation consist in the fact that such dependence allows: to determine a list of tactical techniques of investigative actions; to carry out a choice of that or other tactical techniques determined with those actual data, which are available; to determine not only a list of tactical techniques but their character, concrete content; to establish sequence of performance of tactical techniques with considering of available information.

Activity of investigator on choice of tactical techniques in problem situation presents to be interesting from position of the ICT. It characterized with that or other measure of informational insufficiency, certain contradiction between knowledge and non-knowledge relatively subjected to establishment facts. Psychological structure of problem situation includes: need that made investigator (different variants of the ways of investigator's actions, leading to achievement of one goal or allowing resolving one task, we consider like the techniques); professional opportunity of investigator including his previous experience and creative abilities.

Application of tactical techniques in problem situation requires: preparation of few tactical platforms; opportunity to change a tactical platform in result of unfavourable development of situation; usage of an arsenal of typical systems (subsystems) of tactical techniques of separate procedural actions. 
According to G.A. Zorin, the ICT assumes necessity of investigation of deadlock situations, which presented to be a result of regressive development of problem investigative situation, peak of informational uncertainty on investigated event, absence of visible perspective in positive solution of problems arisen before investigator and which is characterized: with high level of uncertainty, when unknown is more than known about investigated case (at condition that a case long time has been in production of investigator), though deadlock situations are typical and for primary stage of investigation (disclosure) on unobvious crime; with quantity and quality of problems met by investigator, exceeding his physical and intellectual opportunities at their resolution; with absence of result, conjugated to loss of hope at its receiving; appearance of "psychological and notional barriers" disturbing an exit from deadlock [9, p. 36-39].

Founder of the ICT G.A. Zorin proposes non-traditional methods of the exit from deadlock situations: method of critics and selection of ideas; method of heuristic inversion (inverting, permutation); method of heuristic recombination of the elements of investigative situation; method of experimental differentiation (destroying) of investigation's process; method of exclusion of negative factors; method of "sevenfold search" and many others, which, actually, are the elements of the ICT [9, p. 45-72].

Classification of the situations into conflict and non-conflict, borrowed by criminology in psychology is based on characteristics of one of psychological components of investigative situation: rivalry and counteraction of the parties, goals and interests of which do not coincide at crimes' investigation [3, p. 74-75]. In this connection A.R. Ratinov notes that non-conflict situation is characterized with full and partial coincidence of interests of the participants of interaction, absence of contradictions in purposes, to achievement of which directed their efforts at this stage of investigation. Situations of conflicts of various duration and sharpness appear, when between participants of process are formed relationships of competitiveness and counteraction [14, p. 156-158]. Similar division of the 
situations has more psychological directionality allowing only in common features to outline the tactics of investigation and judicial proceedings.

At analysis of problems of the situation it should be distinguished the situations that characterize investigation in whole and such, which appear at conducting of separate actions [6, p. 60-62], characterizing with different quantity and quality of data in concrete moment their conducting. It seems that investigative situation and situation of procedural action are not identical notions: situation of investigative actions has relative independence determining with frames of procedural actions and on volume of notions the situation of investigative actions is the situation of less extent of commonality in comparison with investigative situation; situation of procedural action structurally includes in investigative situation and is its component.

As we noted earlier, situation of investigative action is formed in process of the action and is independence on: availability (receiving) of evidential materials; forecast by investigator of proper tactics; actions of subject, in which addressing the system of tactical techniques [16, p. 431-432].

Elements of the ICT are corrected in process of performance of investigative action that linked with opportunity to change informational data, environment and conditions, at which they are applied. Alteration of tactical techniques and their realization is determined as situation of investigation so and situation of investigative (or other procedural) action.

Situation in its structure has always two sides: material and ideal, which sometimes call external and internal.

Attempts to allocate the components of investigative situation undertook R.S. Belkin, in opinion of whom such situation is formed from the following groups of the components: components of psychological nature; result of conflict between investigator and opposing persons, manifestation of mental features of investigator, persons involving in case etc.; components of informational nature: awareness of investigator (on circumstances of crime, presumptive evidences, opportunities of their discover and expert examination, places of concealment of sought-for etc.); 
awareness of opposing to investigator and other persons involving in case (on level of information awareness of investigator and witnesses, on disclosed evidences, on investigator's intentions etc.); components of procedural and tactical nature: state of production on a case, evidences and their sources, opportunity of alteration of restraint measures, isolation of persons from each other involving in a case, conducting of concrete investigative action etc.; components of material and organizational technical nature: presence of communications between police call centre and operation investigative group, presence of means of information transmission from register sections of the bodies of internal affairs, opportunity of mobile maneuvering of available forces, means etc. [3, p. 69-73].

Not less interests presents consideration of the components of investigative situation by A.N. Gusakov and A.A. Filuschenko analyzing in connection with a choice of tactical technique. They point that in every investigative situation is naturally repeated the following elements: tasks facing investigation at time of application of tactical technique; volume of information that investigator has; material environment at place of application of tactical technique; volume of material, human and temporal resources; interrelations persons, their mental and other particularities [7, p. 12-15].

For creation of effective programme of disclosure and investigation of crimes the especial interest presents a method of generalized situations so named situational modeling, a gist of which consists in the fact that most part of concrete situations analogue in any essential relation, are joined in one or few generalized situations, for which and are developed optimal programmes of decisions made and conducting of practical actions [8, p. 27-30].

Some criminalists note that repeatability of situations creates prerequisites for their modeling, opportunity to outline certain image of actions in process of receiving of criminalistically significant information. It is established that knowledge of modeling situations allows not only foreseeing their appearance in proper conditions like natural but also choosing such tactical techniques, which are more optimal, and also to algorithm the process of investigation [15, p. 155-157]. 


\section{References}

1. Belkin R.S. Kriminalistika: problem, tendentsii, perspektivy. Ot teorii $-\mathrm{k}$ praktike [Criminalistics: problems, trends, perspectives. From theory to practice]. Moscow, 1988, 304 p.

2. Belkin R.S. Kurs kriminalistiki V. 3. Kriminalisticheskie sredstva, priemy i rekomendatsii [Course of criminalistics. Criminalistical means, techniques and recommendations]. Moscow, 1997, 480 p.

3. Belkin R.S. Ocherki kriminalisticheskoi taktiki [Essays of criminalistical tactics]: Uchebnoe posobie [Textbook]. Volgograd, 1993, 200 p.

4. Belkin R.S. Sobiranie, issledovanie i otsenka dokazatel'stv. Suschnost' i metodi [Collection, examination and assessment of evidences. Gist and methods]. Moscow, 1966, 296 p.

5. Gerasimov I.F. Printsipy postroeniya metodiki raskritiya prestuplenii [Principles of designing of crimes' disclosure method] // Voprosy kriminalisticheskoy metodologii, taktiki i metodiki rassledovaniya [Issues of criminalistical methodology, tactics and method of investigation]. Moscow, 1973, pp. 76-82.

6. Gerasimov I.F. Sledstvennyie situatsii na pervonachal'nom etape rassledovaniya prestuplenii [Investigative situations in initial stage of crimes' investigation]. Sots.zakonnost' [Socialistic legality]. Moscow, 1977, no. 7, pp. 6162.

7. Gusakov A.N., Filuschenko A.A. Sledstvennaya taktika (v voprosakh i otvetakh) [Investigative tactics (questions and responses)]. Uchebnoe posobie [Textbook]. Sverdlovsk, 1991, 147 p.

8. Drapkin L.Y. Situatsionni podkhod $\mathrm{v}$ kriminalistike i programmirovanie rassledovaniya [Situational approach in criminalistics and programming of investigation]// Problemy programmirovaniya, organizatsii i informatsionnogo obespechenia predvaritel'nogo sledstvia [Problems of programming, organization and informational providing of preliminary investigation] // mezhvuz. mezhved. 
sbornik nauchikh trudov [Interuniversity collection of scientific works]. Ufa, 1989, pp. 27-32.

9. Zorin G.A. Kriminalisticheskiyi risk: priroda i metodi otsenki [Criminalistical risk: nature and evaluation methods]: Uchebnoe posobie [Textbook]. Minsk, 1990, 89 p.

10. Kolesnichenko A.N., Konovalova V.E. Kriminalisticheskaya kharakteristika prestupleniyi [Criminalistical characteristics of crimes]. Uchebnoe posobie [Textbook]. Kharkov, 1985, 93 p.

11. Konovalova V.E., Shepitko V.Y. Kriminalisticheskaya taktika: teoriya i tendetsii [Criminalistical tactics: theory and trends]. Uchebnoe posobie [Textbook]. Kharkov, 1997, 256 p.

12. Kriminalistika sotsialisticheskikh stran / pod red. V.Y. Koldina [Criminalistics of socialistic countries, ed. by V.Y. Koldin]. Moscow, 1986, 517 p.

13. Obraztsov V.A., Tanasevich V.G. Ponyatie i kriminalisticheskoe znachenie sledstvennoi situatsii [Notion and criminalistical significance of investigative situation] // Sov. gos. i pravo [Soviet state and law]. 1979, no. 8, pp. 109-115.

14. Ratinov A.R. Sudebnaya psikhologiya dlya sledovatelei [Forensic psychology for investigators]. Moscow, 1967, 290 p.

15. Shikanov V.I. Razrabotka teorii takticheskikh operatsii - vazheishee uslovie sovershenstvovania metodiki rassledovainia prestuplenii [Development of theory of tactical operations - significant condition to improve method of crimes' investigation]. Metodika rassledovania prestuplenii [Method of crime's investigation]. Materialy nauchno-pract. konf. [Materials of sci. practical conf.]. Moscow, 1976, pp. 155-159.

16. Shiraliyeva S.J. Integrative tactics of separate investigative actions//Juridical Sciences and Education. Baku, no. 44, 2015, pp. 429-446.

17. Yakubovich N.A. Obschie problem kriminalisticheskoi taktiki [General issues of criminalistical tactics]. Sovetskaya kriminalistika. Teoreticheskie problemy [Soviet criminalistics. Theoretical problems]. Moscow, 1978, pp. 131168. 